$$
\begin{aligned}
& \text { LA-UR -85-3803 } \\
& \text { CE.NIF-85/C.09--8 }
\end{aligned}
$$

\title{
DISCLAIMER
}

\begin{abstract}
Thil report was propared as an account of work uponeored by an agency of the Urilted States Government Netther the Uniled Siales Government nor any agency thereof. nor any nf their omployees. makea any earranty. express of implied. or asumea any logal linbility of responalbility for the accuracy. completeneas. of usefulneas of any information. apparalus. product. of procesu alsclowed. or represents that its use would not Infringe privatoly ownod righu Refor. ence herein to any apocifke commurcial product. process, of service by trado namo. tradomark.

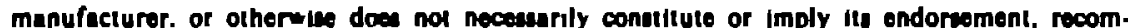
mendalton. of favoring b! the Unitod Stutea Government or any agency inereof The viows and opintons of authon expressed herein do not necesurfly seste or roflect thowe of the Unitod States Coverninent or any acency theroof
\end{abstract}




\section{RADIATION EFFECTS ON VIDEO IMAGERS}

G. J. Yates, J. J. Bujnosek, S. A. Jaramillo, and R. B. Malton Los Aiamos National Laboratory, Group P-15. MS D406

end

Teresa M. Martinez and J. P. Black

EG\&G Los Alamos and EG\&G Kirtland Operations

P.O. Box 809 Los Alamos, NM and P. O. Box 4339 Albuquerque, NM

Television cameras have been used successfully for telemetry of video images from remote experiments invoiving diagnosis of nuclear reactions. Imaging of neutrons, gamma rays and x-rays is accomplished by 1rradiating suitable converters that transform the Incident image to a visible photon Image which is then viewed by IV cameras. Frequently these camersa must operate in high radiation env,ronments resulting from scattering of the Inaident beam. Th1s exposire creates unwanted photocharge that competes with the signal produced by the visible photons, resulting in radiationInduced background bulldup and spurious signals in the final inage.

The primary purpose of these experiments are to (1) compare relative radiation sensitivities or several new TV Iragers with $\mathrm{Sb}_{2} \mathrm{~S}_{3}$ vidioons lour standarc diagnostic for radiation imaging experiments) to datermine if ary offer greater radiation immunity with equal or better visible light sensitivity. (2) to identify reaction thresholds for given sensor types in order to specify shlelding, and (3) to underatand the physics involved when radiation-induced excltation occurs. The results should provide a basis for the optimum selestion of TV syatems for apeciflo imaging axperiments. 
In the past fow years soveral TV Imagers have tecome avallable which offer improvements in speed, sensitivity, and resolution relative to corventional $\mathrm{Sb}_{2} \mathrm{~S}_{3}$ photoconductor-type vidicons. The imagers tested included (1) vidicon type sensors with target materials of sillcon (diode matrix). saticon (Se+Te+1s). Newvicon iznSe), Pasecon (Cdse), Plumbicon and Leddicon $(\mathrm{PbO})$, as well as $\mathrm{Sb}_{2} \mathrm{~S}_{3}$, (2) s1licon-based solld state arrays including charge coupled devices (CCDs), charge injection devices (CIDs). photodiodes (PDAs), (3) photoemissive image intensifiers with bi-alkall S-20 type photocathodes, Including Silicon-Intensifled-Target vidicons (SITVg), proxim1ty-focused microchannel plate tubes (MCPTo), and streak tubes. Then possible, similar samples from different manifacturers were tested to determine "typlcal" performance for glven targets. For most sensors at lesst two samples were measured for improved statistics.

The tests compared measurements of response to visible light and the rodiation sensitivities to noutrons. Bamma rays, and $x$-rays. All sensors showed gamma and $x-r a y$ sensitivity in the form of increased uniform tackground signal as shown in Fig. I for silicon target vidicon. Only the s1licon-based sencors showed slgnificant neutron sensitivity. However, instead of uniform background bullaup, the neutron-inducte slenels appeor as randor spurious "stars" or "speckles" in the vidao 1mage, as shown for the same oli1con vidicon in F1B.?. Other imagers having approximately equal visible light imaging qualities, showed similar responses, with the CCD type belng the moat vulnerable and the older $\mathrm{Sb}_{2} \mathrm{~S}_{3}$ vidicons the least vulnerable to elther samma rays, x-rays, or neutrons. 

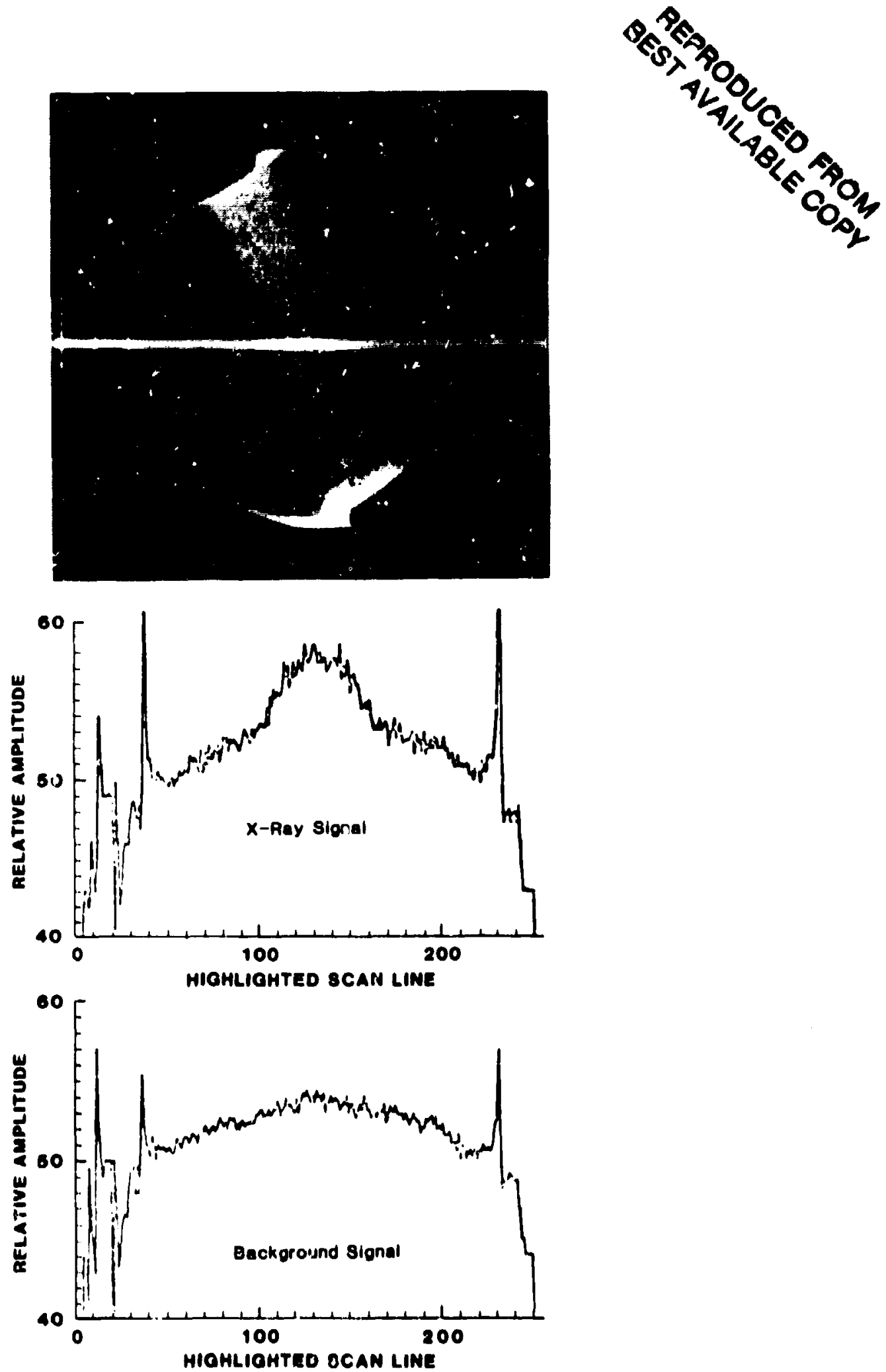

F1g. 1. Response of a vidicon with a ollicon target to a 31-MR, 13-ns pulse of Bremsetrahlung photors fiom an electron Inac. The 1mage show the unf form background produced by the channel-collimated beam. Horizontul 11 ne scans through the center of Imagen (Indlcaled by highlighted band). taken with and without 1rradiation are shown in

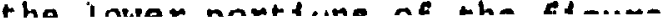



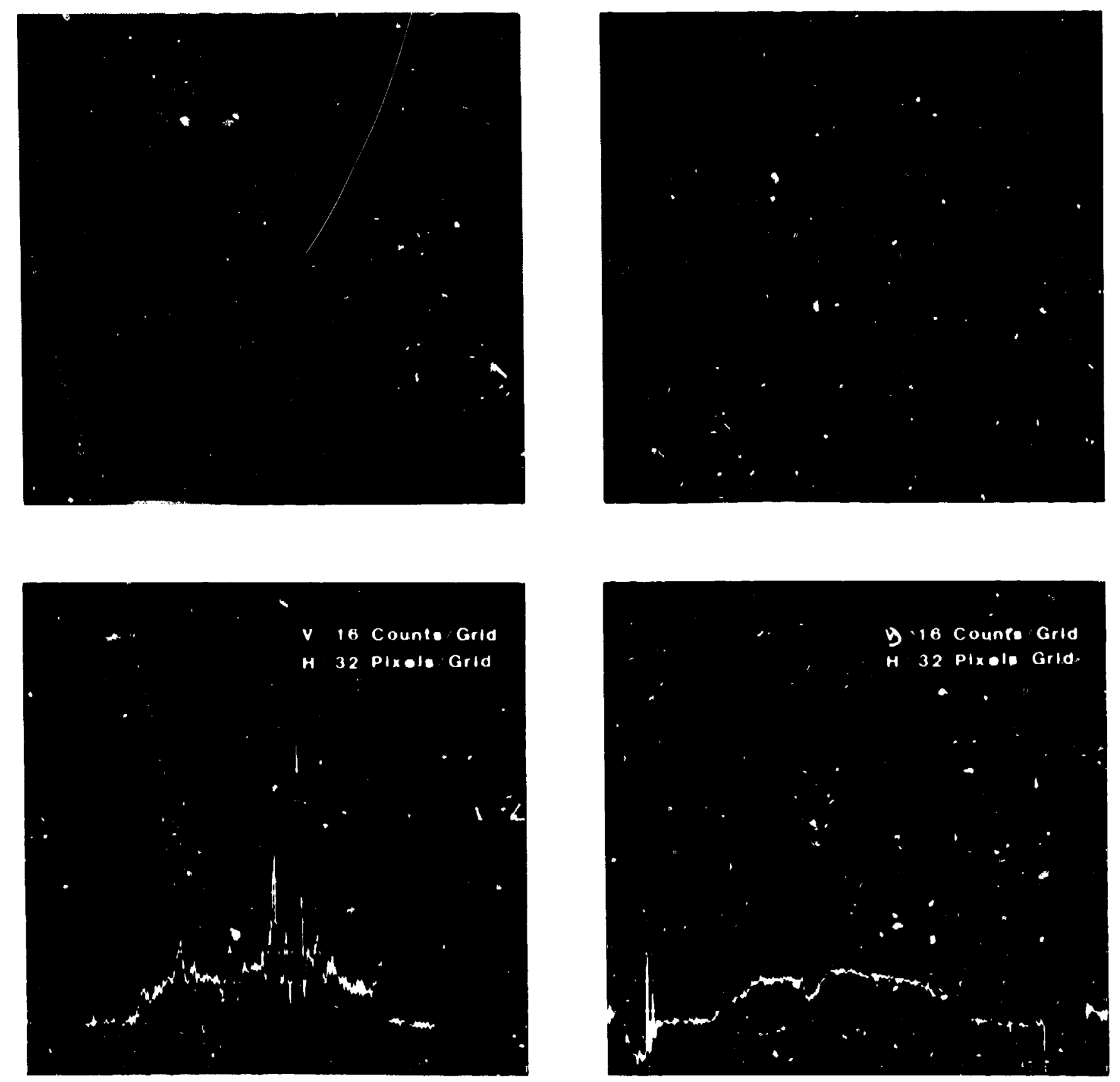

F1g. 2. speckling effects (or "stars") produced by 14 Mev neutron interactions with a sllicon-target vidicon. The Imases I: the upper half of the figure show these effects nt two different flux levels. Horlzontal line scans of these 1muges are shown in the lower purtion of the ilgure. The grid calibrations, $V$ and $I 1$, shown In these scan nlots. refer to a $256 \times 512$ dioftal nrosantattan ar 
G. J. Yates, J. J. Bujnoeek, S. A. Jaranillu, and R. B. Walcon Los Alamos National Laborecory, Group P-15, MS D606 P.0. Box 1663, Los Alamos, New Mexico 87545

and

Teresa M. Marcinez and J. P. Black

BGGG Los Al mos and BGsG K1rtland Operatione

P.0. Box 809 Los Alasos, NM and P.0. Box 4339 Albuquerque, MM

\section{Abetrace}

Radiation eeneicivizy of eeveral photoconduccive, photoeniseive, and eolid scare ellicon-based video lasgers was aseured by analyalng scored photocharge induced by Irradiation with continuous and puleed sources of high anergy photons and neurrora. Iraneient effecte as functions of abeorbed dose, dose race, fluences, and úulzing particle energy are presenced.

\section{Incroduction}

Indirect Ienging of neutroat, erene raye, and $x-r a y=$ Io accopliahed by irrediecing sulcable convartere thet crenpfore the incident inane to a vible photon Inere which is then viewed by IV Inngere. Scetcerlng of the incideat 1 ux exposes the Inagers to Ionising rediation. Inis creates uwented phorocharge that competes vith the eignal produced by the vielble phocons, revulcing in radiacion-induced background bu1ldup and epurious amale in the final inage.

The priany purposes of these experimente are co (1) compare relacive radiaticn ansicivicies of geveral IV leagere with $\mathrm{Sh}_{2} \mathrm{~S}_{3}$ vidicons (our etandard

diagnoets for rediacion laging experimente) to determine if any offar grenter radiacion inmicy with equal or betcer vieible litht eeneitivisy. (2) to Idencify reaction chreuholde for atver eeneor eypes in order co epecify ohieldins, and (3) co underetand the physice involved then pixel excicerion occure.

\section{Ienere Bvelunted}

Inngere teeted Included (1) vidicon cype sensora with che following careet meerialet $\mathrm{Sb}_{2} \mathbf{s}_{3}$ photo-

conductore I, II, and IV, allicon diode matrix, eatIson (Se+Teth), Nervicon (znse), Pesecon (Cose), Plum olcon and Laddicon (PbO); (2) eilicon-baead eolid cete srraye including charge coupled devices (CCDE) charge injection doviecs (CID), photodsodes (PDAR);

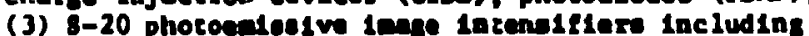
s111con-Intensified-Target Vidleone (EITVo), proxiateyfocuead alerochennel plate tubes (MCMe), and etreak

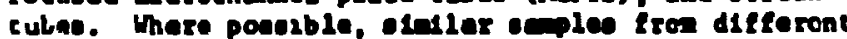
ennufecturere were ceoced to deterilae "cyplcal" performnce for iven tergote. Por wost enoore at leat ewo anplea were seasured for inproved atatineice.

\section{MAtution gouren}

Th. cources used restricted fluxes and fluences to low levele that senerally produced only traneient

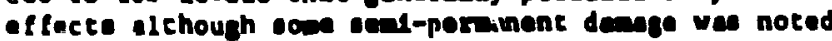
for CCD. The eources included

(1) Conesnuous tluxes of $1.25 \mathrm{MaV}$ (1.17 $\mathrm{moV}$ and $1.33 \mathrm{MaV})$ and $662 \mathrm{KaV}$ gene raye froe leotople ourc is ${ }^{60} \mathrm{Co}$ and ${ }^{137} \mathrm{Ca}$. reepectively. Maxicue doese rates of 77R/a were avallable froe ${ }^{60}$ Co and $0.34 R / 0$ from ${ }^{137} \mathrm{Cs}$

(2) 1 to 80 ne duracion burste of Brementahlung photune (average energies in the 3 to $4 \mathrm{keV}$ range) produced by bowberding a $50-11$ tungecen carget wth 8-12 MoV ele trons fron a Linac.

(3) Cont 'nusus flux of tiasion neutrons froe ${ }^{252} \mathrm{cf}\left(4 \times 10^{7} \mathrm{n} / \mathrm{a}\right.$ at the eurce).

(4) Meropocond duration ( 1 to $10 \mathrm{wo})$ burete of $14 \mathrm{MaV}$ neutron froe a D-T eenlestetse generator vith exicue tlueace of $t 1.0 \times 10^{7} \mathrm{n} / \mathrm{co}^{2} / \mathrm{pulse}$

(5) Vanbebraeff acedieratore to produce nowoenergetir neutrono in the range frse 400 tav to $10 \mathrm{kl}$ ueing $L 1^{7}(p, n)$ and $H(T, n)$ react $10 n$ to ecudy $81(n, p)$ and $S I(n, \alpha)$ reections in the allicon-besed Ingert. For neutzon enerzios below $1.1 \mathrm{MVV}$, DC irredietsone vere eade with exinu fluxes of $₹ 5 \times 10^{7} \mathrm{n} / \mathrm{e}^{2}-$. At higher energles, pulead Irradiazions were ade wth neutron fluencen of $\approx 3 \times 10^{5} \mathrm{n} / \mathrm{cm}^{2} /$ pulee produced $\mathrm{ty}$ gating the acceleretor bere for $: 2=$.

\section{Experiment satupe and Revule}

\section{Geven Roy weguromes}

Figure 1 bhow the bestc geme ray irredistion cecup. A ono-Inch diemeter colliketcr and a 1/b-luch ude allt vere used to provlde contrent between irreslated and non-1rredieted arees on the TV corbate. Gere ray flux lovelo wre varied by poestecaln the carpets at vartous diecences frow the coures an by uning leod bricke in the rediction path for atecaucten. The vides algane: froe the Imagere ves risued of a TV eonitcr and recorded on en onellleseope.

The aplif1er Fis (fleld effect trangletere) wre Irradiaced firer, wehout ony inage in the $T$

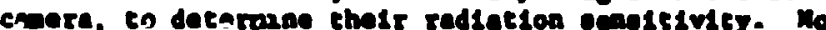

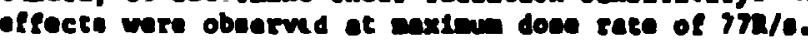

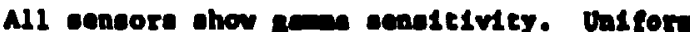

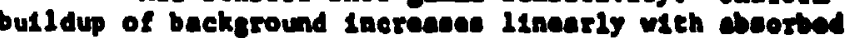

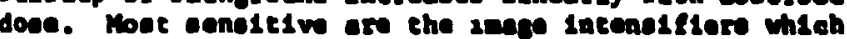

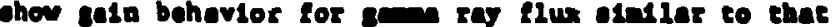
for viaibla light flux indleating th dendrant germ rey effect to co cause photociteston froc the -20 photocathode. Roverveblasing of photocatbodes or

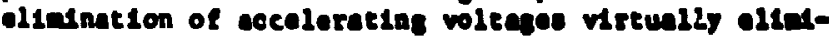

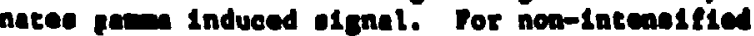

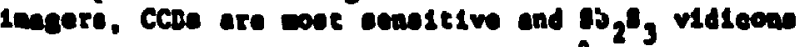

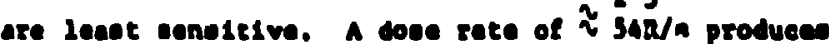
elenal-to-nolee racios (e/I) of 93/1, 65,1, s0/1, and

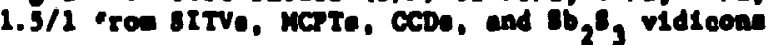

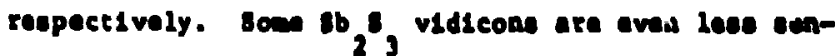

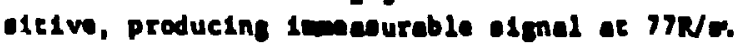




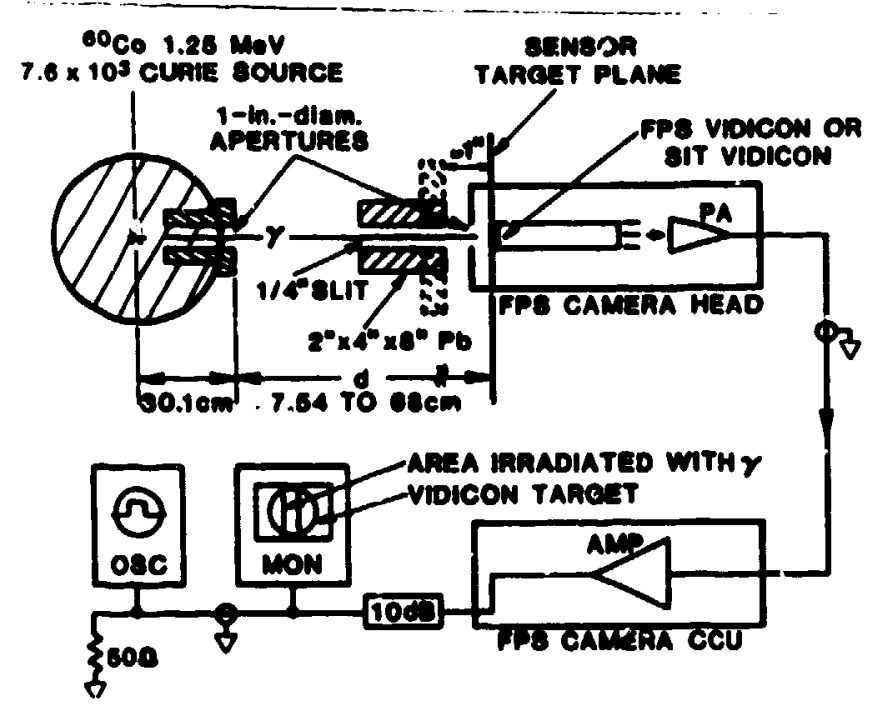

Fig. 1. The bastc Cobalt 60 gana Irradiation setup. The eource etrength $107.6 \mathrm{kllocur} 1 \mathrm{es}$.

The everage $s / N$ noted for other vidicon photoconductors wee $12 / 1$ fer Pbo, 6/2 for enticons, $2 / 1$ for CdSe or Znse. Our wasuresente whow that the relative visible light eeneltivity at discrote wovelength bande 1. higher for PbO and eaticon target vidicon than for chose with cdse or znse. Therefore, their higher eensitivity to geme rediation any be due to better inherent quancun efflciency. Game-ray ceneltivity of the other 111 con-besec' Ingere, 1,e., the e111con target vidicon, CID, and PDA lies between that of the above photoconductors and $\mathrm{Sb}_{3} \mathrm{~S}_{3}$. The image intenelfler and silicon ianger reeponste are plotted in P1B. 2 and sumarleci in Table I.

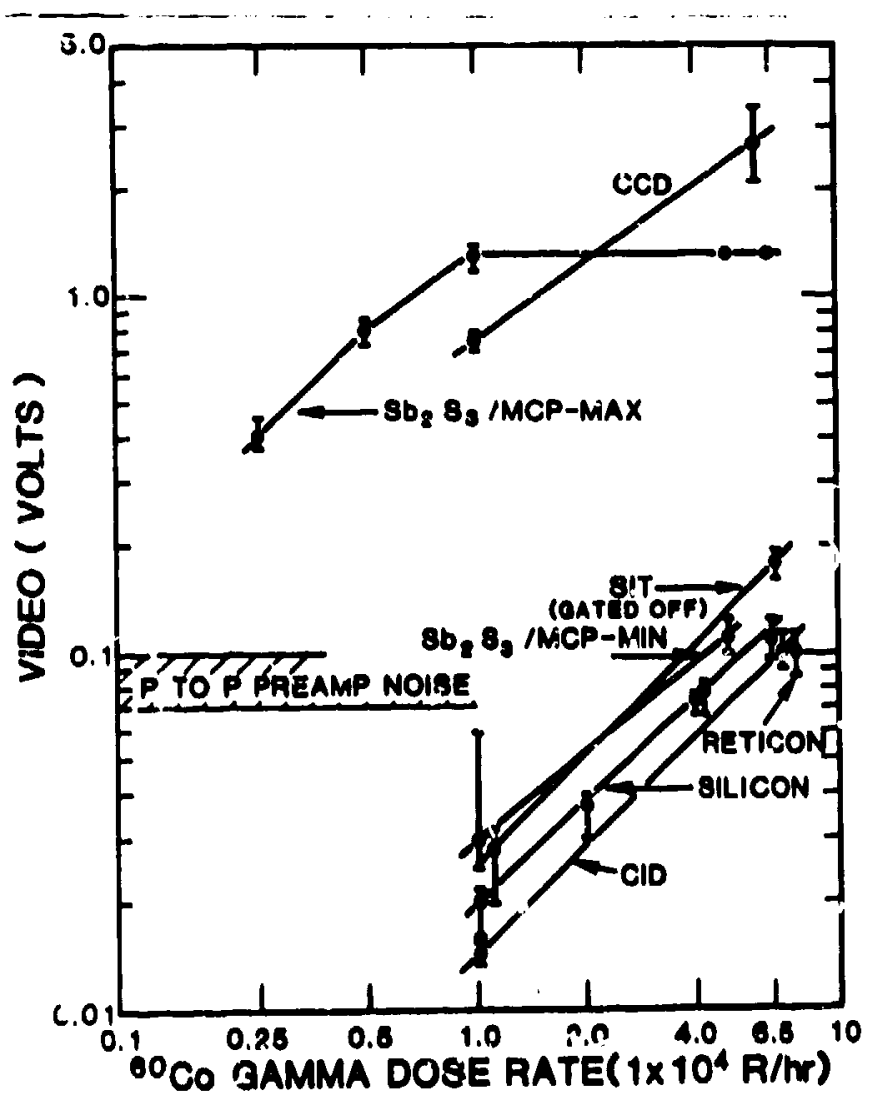

Nig. 2. Grma ray reapone for ell1son typa TV Imagere and two 8-20 based inge intenelfiers.
TABLE I. Cobalt 60 genae ray responses

Model

Dose Rate Row Borma-
Target

GE 85731

RCA 85734

Helanann X01292

EEV PBO38B

EEV P849D

GE 7803 :

GE 7803 i2

HeImann AN456

Themeon 9950 (D)

Amperex X01021

Amperex X02172 (D)

EEV P8022

EEV P8490 (D)

He1nann X01 461

Imperex X01442

GE $7803 S 12$

monson THX 865

GE 178 :1

GE 178 12

Fairoh1ld 222

Retioon

GE 7821

(Hy on)

(HV off)

ITT FA11/Ge 78031

(HV on, geted on)

(HV on, gated off)

(HV O.:T)

.CAC73435/GE7821

( STK HV on . coted

on, SIT HV on)

STK HV orf, SIT HV on)

(STK HV on, coted

off. SIT HV on)

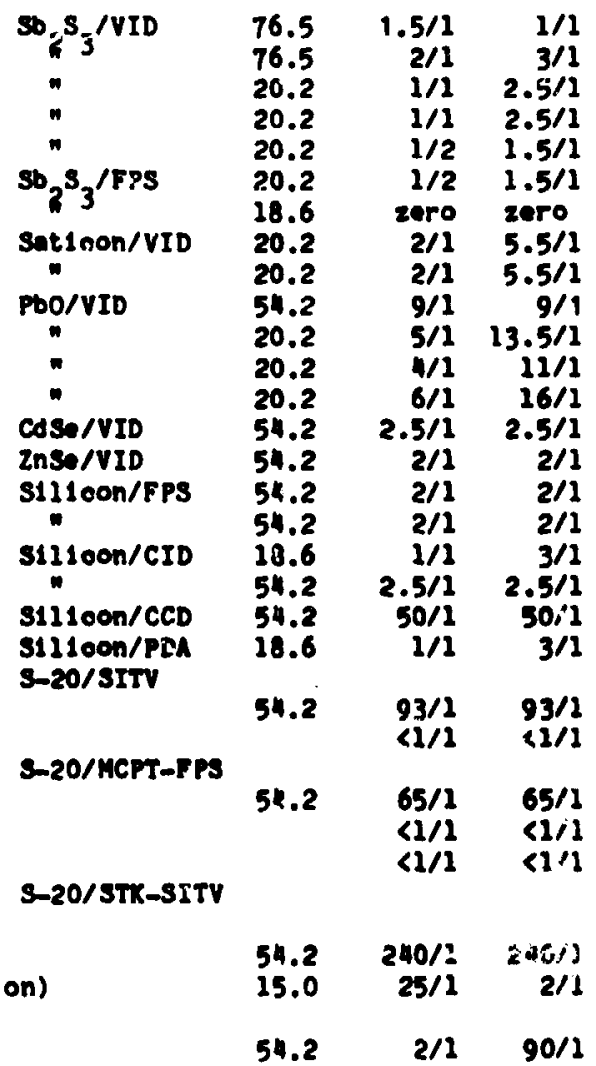

\section{Bremetrahlun Irred1atione}

S1ediar collinetion and alt arrangerent was uned to provtde contrant in the vidoo al ganl. The Linac was eynchrnnized to the TV arne and puleed once every flfth TV fleld, giving esectitelly olngle pulee respon s. The dose per pulee was reatured by exposing therwoluninescent dosimere (ILDE) at the IV target plane. The . vpone for a el11con target vidicon to a 31 n111:ads axposure from 13 ne FWM $x$-ray burnt 1. hown In F18. 3. The $1 / M(A 5 / 1)$ obeerved for this doee 10 in rood arreenont with $8 / 4(\approx 6 / 1)$ frm $\tilde{\imath} 36$ alllirade cteo-integrated $3 \mathrm{~m}$ (IV fld peried) dose from ${ }^{60}$ Co gemen, Indlcatins a dependency on total dne rather than on dose rate. The $x$-ray reepone for this eneor 10 ILnear between 31 and 065 allirade with saturution occurring ot $* 1.1$ rado. A 26 ne FHM, 62 a111red exposure caused eaturezion in the cco inager. Indicatiag $\AA$ 18x higher $x-$ ray enestivity for this censor.

\section{Neut son Irred1at 10,10}

For the undinteasteded lagere, only the allicon-based unite ohow algniflcant neutron eanestivity. Neutrone produce epetialiy randon axcltation of ladi-

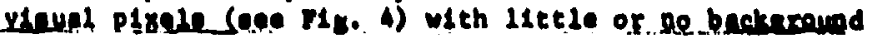
bulldup. The 8-20 $\mathrm{m} / \mathrm{T} / 8 \mathrm{~b}_{2} \mathrm{~s}_{3}$ intenest1er mhowed no Individual interactions, but howed background bulid-

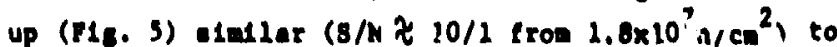
16 gabe reaponee ( $\sin$ is $4 \mathrm{~s} / 1$ rom $1 \times 10^{8} / \mathrm{cr}^{2}$ ). 

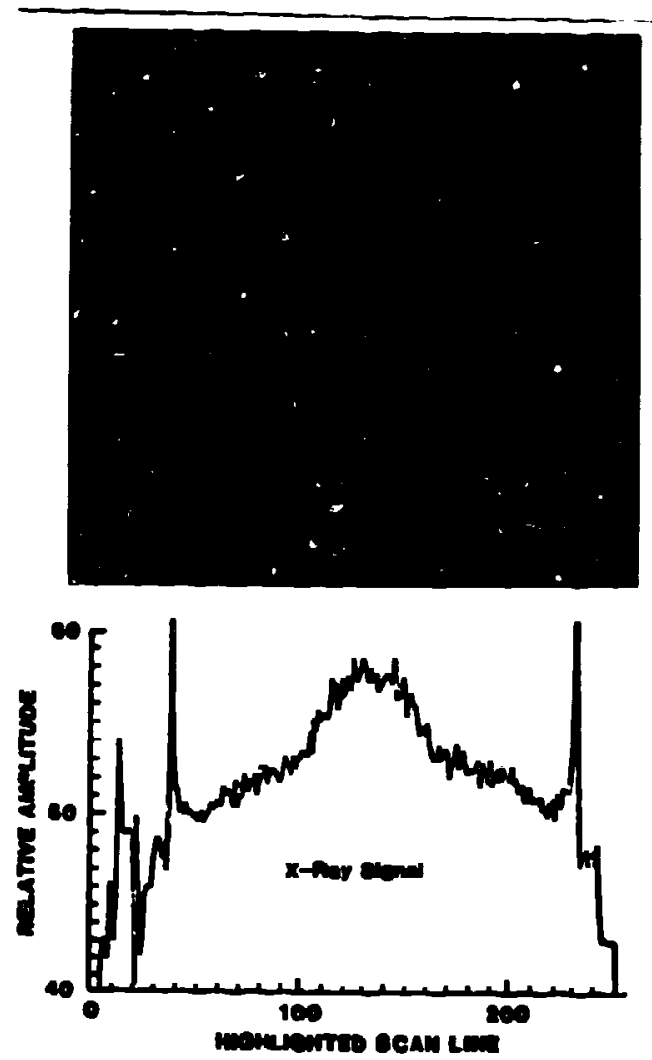

Fig. 3. High energ photon Induced eignal in e1licontarget ips vidicon.

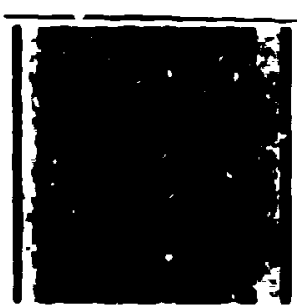

a. Falrchl1d CCD-1

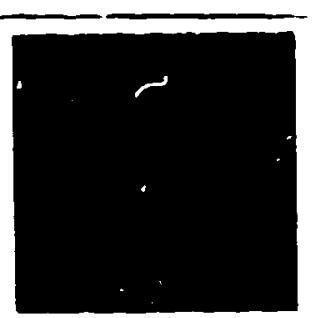

C. GE CID

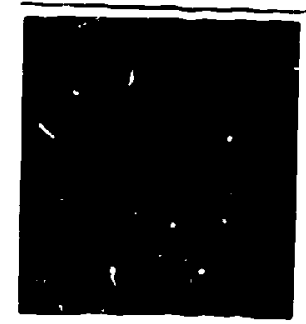

b. g111con vidicon

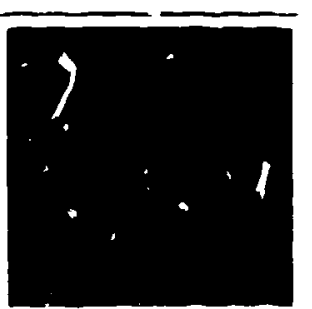

d. Reticon
F18. 6. Neucron-1nduced opeckling for eaveral e111conbaeed TV Inagers when Irradieted with 14 MoV tluence of $\approx 4.5 \times 10^{5} \mathrm{n} / \mathrm{co}^{2}$.

The expected number of Individual incerac: Ion fron allicon neutron crose-pection calculation araes well (utehin experientel accuracy and lint ted catietsce avallable) with obner ad counte (eae Iable II for is MvV reeponed) of affected plxale for

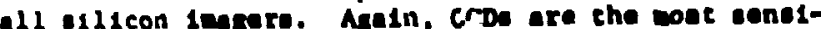
cive teasere (2 1133 ince ctione eron $4.3 \times 1 \mathrm{C}^{6} \mathrm{n} / \mathrm{ce}^{2}$ ). Pulse neight and ares dietrituting of excited pixele for CCD Il fron puleed 1 ra-:Iation ulth monoenergetic neutrons of $z, 6,8$, and $10 \mathrm{MeV}$ are found in Table III and F1g. 6. Comparing the 6 and $8 \mathrm{kaV}$ date with the 4 MeV data shore the relacive contrtbutione of $(\mathrm{n}, \mathrm{p})$ and $(n, \alpha)$ reactions. Excication with ${ }^{252} \mathrm{Cf}$ fionton apectron neutrono produced a onller ratio of securaced pixels versus total affected pixela chan racios obcaired frot higher energy neutrone.

Reduction of radiacion effects by sintelding vas Invertigated. Star effecta in the ellicon vidicon, mancing to 33 stare froe en exposure of $2.8 \times 10^{5} \mathrm{n} / \mathrm{cm}^{2}$. vere essentially elininated by ohtelding wich elther $30.5 \mathrm{cr}$ of polyethylene or $9.2 \mathrm{~cm}$ of tunpeten. These shielda represenced 2-3 sean free pathe for the etcenuncion of $14 \mathrm{MeV}$ neutrone.

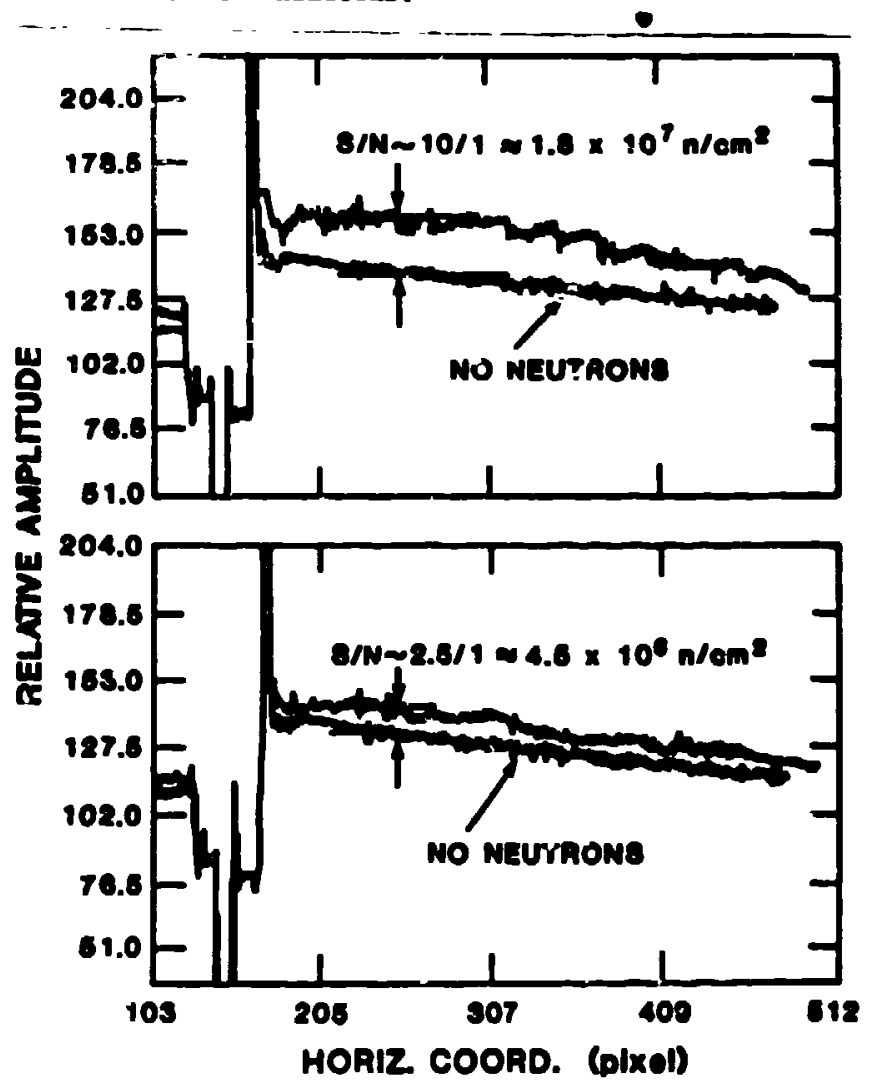

FI. 5. Neutron-Induced beckground (with no apeckling) In $8-20$ based inge Inzensigier from irradse elon w1ch 1-10 ue burets of $14 \mathrm{kaV}$ neutroas.

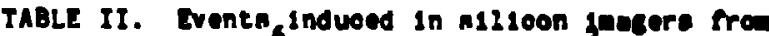
$4.5 \times 10^{6}$ in MV neutronarou

\begin{tabular}{|c|c|c|c|}
\hline Model & $\begin{array}{l}\text { Totel of } \\
\text { Pixele }\end{array}$ & P1xele/on & $\begin{array}{l}\text { Totel } \\
\text { Evente }\end{array}$ \\
\hline of T803s/FPs & $2.8 \times 10^{6}$ & $1.4 \times 10^{5}$ & 336 \\
\hline $\mathrm{FL}-222 / \mathrm{CCD}$ & 185.410 & $1 \times 10^{5}$ & 1135 \\
\hline ac178 1 & $96,22 n$ & $1.57 \times 10^{5}$ & 108 \\
\hline notsoon/PDA & $1 \times 10^{11}$ & $0.5 \times 10^{5} 14$ & 14 \\
\hline
\end{tabular}

The effective auber of plmale/on for $\cos 11$ reflect epproxteately 30 inevnattiw erea betwen pixele. For the olilicon vidicon, effeets pixel aree 10 che ₹ 30 undlaneser electron beer, rather then the 7 un diencer eilicon diode. 


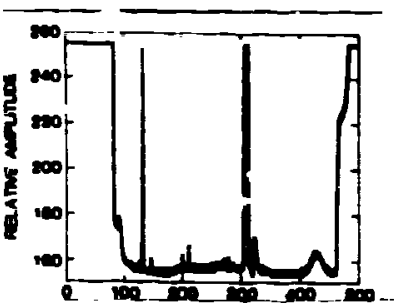

RORIZONTAL COORD (PIXe1) a. $4 \mathrm{mav}$

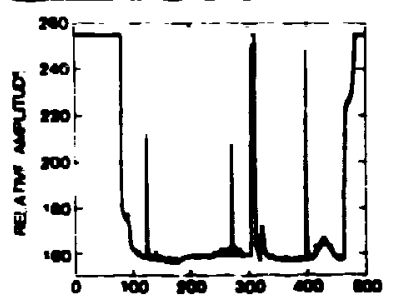

HORLZONTAL COORD (PIxel)

c. $8 \mathrm{MeV}$

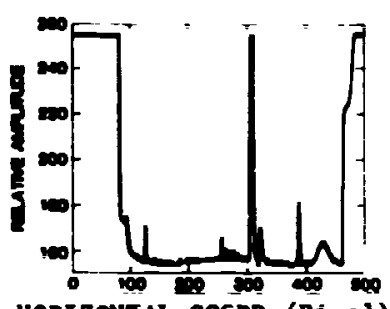

hORIZONIAL COGRD (Pixel) b. $6 \mathrm{HeV}$

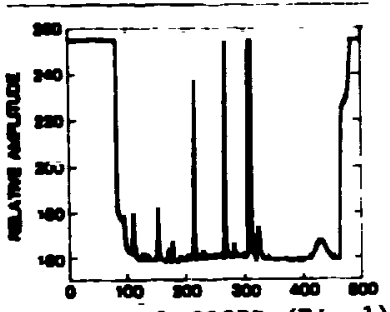

AORIZONTAL COORD (PIxe1)

d. $10 \mathrm{kaV}$
Fig. 6. CCD video lines through affected pixels. Each piot is an overlay of chree randoe lines.

Iable III. PIxel ares and aplicude dietribuctions from neutron Induced apeckling in CCD 11 from $3 \times 10^{5} \mathrm{n} / \mathrm{cm}^{2}$ fluence.

$\begin{array}{lcccl} & \text { G MV } & 6 \mathrm{MoV} & 8 \mathrm{meV} & 10 \mathrm{MeV} \\ \text { P1xels } & 52 & 42 & 85 & 1.2 \times 10^{3} \\ \text { Area range } & 1-4 & 1-6 & 1-6 & 1-22 \\ \text { Avg. ares } & 1.6 & 2.6 & 4.0 & 6.2 \\ \text { Anpl range } & 165-210 & 166-227 & 165-256 & 165-256 \\ \text { Avg. amp1 } & 170 & 191 & 175 & 175\end{array}$

\section{Coricie'ion Between Heasurements and Calculatione}

Several reactione of neucrone with ellicon nucles that produce lonising particles include elastic and inelatic acatcering, $(n, p)$ and $(n$,$) . The parti-$ cles creace electron-hole paris as they pase through the allicon subetrate. C..--iers produced $1 r_{\text {device }}$ depiecion regions, or ulchin a diffuetion length of these regione, ars ecored as photocharge which is readout lacer as video elgnal fror the TV imager. Becauee of the whort range of ecactering recolle and sharged secondary particles, wet of the energy deposiced as lonizacion occure vithin the acerial where the reacclon ocfurs. Consequantly a ingle reaction can thou up a a local effect or a etar in one or a fer contiguous pixele on the IV smagere. In contraet, the unergy lose per unic diecance of electrone produced by the inceraction of hith energy game raye 10 emaller, re:ulcing in the wore uniform goneral beckground buildup noted for photon Irradiatione.

The range of video eignal asplicudes mecisured froe the noise level to ecturation (where the charge) may be ecored by eeveral nalghboring ( 1 ixele) are consieten: vith calculetione of the nubber of electronhole feire produced a a iunction of incident neutron energy and the pixel eeneleivity. (a function of explifier noine and carget quicun efficiency), and the charge capectey (the nubber of electrono/well for solld tace ingere or holes/diode for oll1con-target vidicune) The nole threshold range for the various imeger manplifier combinatione correeponde to 25 to 100 ulectrone and ectintes of pixel cherse capecity $(1,2,3)$ renge from $>10^{3}$ co $>10^{6}$ electrons/oixel. One atudy (4) reporte that 1) recolls in the active ellicon reglon produced by neutron ecattering produce from $\chi 7 \times 10^{-70}$ to $3.2 \times 10^{-19} \mathrm{C} / \mathrm{m}^{3}$ per $\mathrm{n} / \mathrm{cm}^{2}$ for neutron energies from $Z 300 \mathrm{keV}$ to $4 \mathrm{keV}$. Increasing to $₹ 6 \times 10^{-19} \mathrm{c} / \mathrm{m}^{3}$ per $n / \mathrm{cm}^{2}$ at higher energies, and 2$)(n, c)$ and $(i-p)$ reactions produce from bout $1 \times 3 \times 10^{-20} \mathrm{C} / \mathrm{mos}^{3}$ per $\mathrm{n} / \mathrm{cm}^{2}$ at $\imath 4 \mathrm{HeV}$ Increasing to $\approx 2 \times 10^{-18} \mathrm{c/m} \mathrm{m}^{3} \mathrm{per} \mathrm{n} / \mathrm{cm}^{2}$ In the range from $8 \mathrm{HeV}$ to $14 \mathrm{kaV}$. The reaulting total range 1. $₹ 7 \times 10^{-20}$ co $5.4 \times 10^{-18} \mathrm{c} / \mathrm{w}^{3}$ per $\mathrm{n} / \mathrm{co}^{2}$. The effeceive $S 1$ voluelpixel is $73 \times 10^{-6}$ for aliscon vidicon and $\approx 2 \times 10^{-5}{ }^{3}$ for $C C D$ and CIDe used in this etudy. Uaing the $3 \times 10^{5} \mathrm{w} / \mathrm{cm}^{2}$ fluence fron the Vandegraeff experiments and the ebove range of poestble charge. 8 tres $Z 2.6$ to 508 oh patro/pixel for CCDe or CIDe and $t 0.4$ to 77 e-h paira/pixel for eilicon vidicons. We belleve this to be expected average charge/pixel, but because only a anall fraction of the total pixcle are affected, chair actual charge/pixel io much larger. Exanination of the CCD date fro Table III thow t $1.2 \times 10^{3}$ affected pixele out of $1 \times 10^{5}$ avatlable plxele giving 83x everage charge or 217 tu $4.2 \times 10^{4}$ eh palre plxel, wich is eufficleat to produce ignals from noles to saturatior for thle leager.

\section{Acknowledresente}

The authore with to acknowledge help with game roy measuremente provided by $R$. Head of licse lae vegen help with neutron eanurcante provided by $L$. Sprouse, $P$. Weles of Los Alawos Mactonal Laboratory and $\mathrm{B}$. S1 wons of Sandie National Laboratory: help in neutron reaction celculacions and meseuremente provided by B. Noel, R. Haight of Lon Aleos Mational Laborator? and J. Karmarraad of Lewrence Livernore Laboratory; help utch daca reduction by $R$. Liljestrand, H. Lopex, and $M$. Cheverria of RGG Loe Alamo.

\section{Referencen}

1 G. J. Yates, HIgh Resolution SIT IV Tube for Subianosecond Inage shutertas, Loo Alasos Nacional Laboracory repore nuber LA-9771-NS, Sepeceber 1984, PP, 10-15 and Pp 3-75.

2 J. M. K1lliany, Radiation effecte on Silicon Charge-coupled Devices, IEE. Iraneaceion on Componencs, Hybride, and Manufacturing Technolosy, Vol. Chil-1, No. 4, December 1978, pp. 275-287.

3 A. Brose, High Resolution, Posicton eenitive solid state Detectora Ucilising the CCD Concept, 8111con Detectore for High Enery Phyelee, proceedinge of Ferailab workehop, Oct. 15-16, 1981. PP. 127-168.

4 R. Kuckuck, 8entconductor Detectore for Uee In the Current Kode, Imwrence indietion Laboratory Repore fuCRL 51011 . February 10, 1974, Pp. 10-13. 